\title{
Léčiva $v$ pitné vodě a vliv médií
}

\section{František Kožíšek, Petr Pumann}

Envigogika 8 (3) - Recenzované články/Reviewed Papers

Publikováno/Published 15. 10. 2013

DOI: $\underline{\text { http://dx.doi.org/10.14712/18023061.388 }}$

\begin{abstract}
Abstrakt
Článek shrnuje výsledky výzkumného projektu o sledování léčiv v pitných vodách $\checkmark$ ČR a hodnocení jejich rizika a informuje o komunikaci výsledků projektu skrze média. Některá $z$ médií se snažila $v$ titulku nebo i perexu zprávy výsledek výzkumu obrátit a čtenářům sugerovat, že léčiva v pitné vodě představují hrozbu, což ale výzkum neprokázal a související tisková zpráva neuváděla ani nenaznačovala. Článek se zabývá možnými př́činami, proč média takto jednají, a strategií, jak otevřeně sdělovat výsledky výzkumu veřejnosti, aniž by došlo $\mathrm{k}$ jejich zkreslení.
\end{abstract}

\section{Klíčová slova}

pitná voda, léčiva, veřejnost, vnímání rizika, komunikační média

Drugs in Drinking Water and the Impact of the Media

\begin{abstract}
The paper summarizes the results of a research project that monitored the incidence of pharmaceuticals in drinking water in the Czech Republic and their health risks, and discusses the communication of such results to the public through mass media. Some media tried to change the meaning of the results in their headline and the introduction to their report and suggest to readers that pharmaceuticals in drinking water pose a risk, although the research did not prove this and the related press report did not mention or even suggest it. The paper discusses possible reasons why the media behaves in such a way, and strategies for how to openly communicate research findings to the public without them being misinterpreted.
\end{abstract}

\section{Key words}

drinking water, pharmaceuticals, the public, risk perception, mass media 


\section{Úvod}

Je tomu již více než deset let, co se v tuzemských médiích začaly objevovat zprávy, že pitná voda obsahuje nebo může obsahovat stopy léčiv včetně hormonálních př́ípravků. Frekvence těchto zpráv není sice př́liš vysoká, ale objevují se celkem pravidelně. I když $\checkmark$ jejich pozadí bývají obvykle nějaké pravdivé zprávy ze zahraničí, tuzemská informace bývá většinou zkreslená nebo i zcela překroucená (např. nález v říční vodě se zaměňuje za nález $\vee$ pitné vodě (Anonym, 2002)), popř. nebere $v$ úvahu odlišnou situaci $\vee$ České republice (ČR).

Teoreticky Ize takový jev připustit: Zbytky nemetabolizovaných léčiv jsou vylučovány převážně močí a odpadní vodou se přes čistírnu odpadních vod může jejich část dostat do povrchových vod. Pokud je voda z takového recipientu níže po proudu využívána jako zdroj surové vody pro výrobu pitné vody a úpravna vody nemá dokonalou technologii úpravy, mohou se stopy některých léčiv skutečně dostávat i do pitné vody. Cest, kterými se humánní léčiva mohou dostat do pitné vody, je samozřejmě více (viz obrázek 1), ale ta naznačená je hlavní.

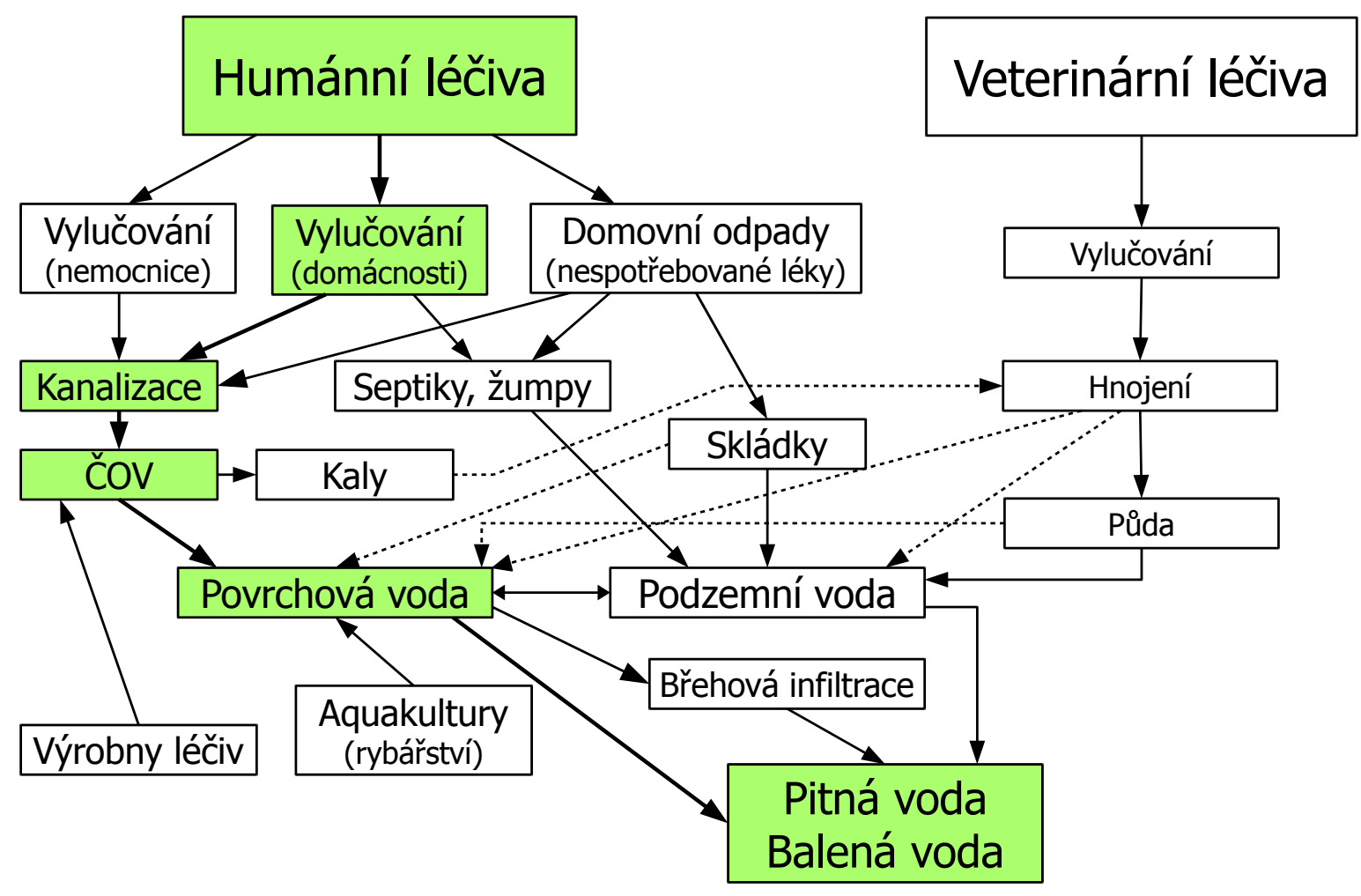

Obrázek 1: Schéma možných zdrojů a cest výskytu léčiv ve vodním prostředí (upraveno podle Heberera (2002)).

Dosavadních nálezů z pitné vody je však relativně málo, jsou velmi nízké a většinou pocházejí z vodáren, které musí odebírat surovou vodu z dolních toků velkých řek (Kožíšek et al., 2010), kde nelze uplatnit stejnou ochranu vodního zdroje jako je tomu u vod 
podzemních nebo u vodárenských nádrží situovaných na horních tocích řek. Tato problematika se dostala do středu odborné pozornosti poměrně nedávno jen díky tomu, že pokroky $v$ analytické chemii umožnily stanovovat stále nižší a nižší koncentrace sledovaných látek.

Údaje ze zahraničí mohou být $v$ ČR využity jen částečně, protože objem i struktura spotřeby léků, ochrana zdrojů vody, podíl využití povrchových a podzemních vod $\mathrm{k}$ výrobě pitné vody a využívané technologie úpravy vody se liší stát od státu. Vzhledem $\mathrm{k}$ tomu, že jen polovina objemu pitných vod se u nás vyrábí z vody povrchové a ve většině případů se jedná o odběry z chráněných vodárenských nádrží, které bývají odpadními vodami zatíženy jen minimálně či vůbec, jsme od počátku nepovažovali výskyt léčiv $v$ pitných vodách $v$ ČR za aktuální problém. Avšak vzhledem k množícím se zprávám v médiích (např. Pitná voda může škodit zdraví, www.idnes.cz, 23. 4. 2007; Vědci varují před zdravotními vlivy reziduí, Medical Tribune, 2. 5. 2007; Miliónům Američanů teče z kohoutku voda se zbytky léků, www.novinky.cz, 10. 3. 2008 atd.) a rostoucí obavě části veřejnosti se ukázalo potřebné získat konkrétní údaje o národní situaci, aby mohl být proces informování veřejnosti o rizicích podložen konkrétními a vědeckými důkazy relevantními pro ČR.

Proto $v$ letech 2009-2 011 proběhl první systematický screening léčiv $v$ pitných vodách v rámci výzkumného projektu "Výskyt a zdravotní rizika zbytků humánních léčiv $v$ pitných vodách", který prováděl Státní zdravotní ústav Praha (SZÚ). Cílem této práce bylo provést studii výskytu zbytků léčiv $v$ pitných vodách $\vee$ České republice, zhodnotit expozici vodu konzumující populace a z ní plynoucí míru zdravotního rizika, a o výsledcích informovat odbornou i laickou veřejnost, popř. též doporučit další opatření ministerstvu zdravotnictví a výrobcům vody, pokud by si to situace vyžadovala. výsledky studie byly publikovány podrobně jinde (Čadek et al., 2012; Kozisek et al., 2013) a jsou též dostupné na webových stránkách Szú (http://www.szu.cz/centrum-hygieny-zivotnihoprostredi/vyskyt-a-zdravotni-rizika-zbytku-humannich-leciv-v-pitnych), proto je zde uvádíme jen stručně, pro kontext celého sdělení.

\section{Metodika studie}

Pro screening bylo vybráno pět látek. U čtyř - naproxen, ibuprofen, diclofenac (vše protizánětlivé a antirevmatické př́pravky) a carbamazepin (antiepileptikum) - se na základě nálezů ze zahraničí a struktury spotřeby léčiv $v$ ČR jevil jejich pozitivní záchyt jako nejvíce pravděpodobný; pátou byla hormonálně aktivní látka 17a-ethinylestradiol (steroidní kontraceptivum), která má sice dosud nízký záchyt v pitných vodách, ale mediálně i mezi laiky je nejvíce diskutována. Pro stanovení byla použita metoda GC/MS s mezí stanovitelnosti (MS) na úrovni $0,5 \mathrm{ng} / \mathrm{l}$, pro $17 \mathrm{a}$-ethinylestradiol ve druhé a třetí etapě pak $2 \mathrm{ng} / \mathrm{l}$.

Cílem první etapy vzorkování byl základní reprezentativní screening zahrnující všechny kraje ČR a hlavní vodovody tak, aby bylo dodrženo poměrné současné zastoupení zdrojů podzemní a povrchové vody. Bylo odebráno 65 vzorků pitných vod využívající jako zdroj surové vody povrchovou vodu (nebo vodu smíšenou s vodou podzemní) a 27 vzorků pitné vody z podzemních zdrojů, celkem 92 vzorků z 92 různých vodovodů. Vzorky byly odebírány $z$ kohoutků náhodně vybraných veřejných budov $v$ distribuční síti. Tyto vodovody zásobují celkem asi 3,9 mil obyvatel.

Ve druhé etapě byl odběr vzorků upravené pitné vody zaměřen na kritické lokality úpravny vody, které využívají jako surovou vodu povrchovou vodu z dolních toků řek, zatížených odpadními vodami (20 lokalit), popř. úpravny, které $v$ těchto místech 
neodebírají vodu prímo z toku, ale využívají břehovou infiltraci (3 lokality). Vzorky upravené pitné vody byly odebírány na výstupu z úpravny před vstupem do distribuční sítě. Tyto úpravny vod zásobují celkem asi 2,5 mil obyvatel. Protože část vodovodů z první a druhé etapy se překrývala, celkové pokrytí vzorkováním obou etap představuje asi 5,3 mil obyvatel.

Třetí etapa vzorkování byla zaměřena na ověření vyšších koncentrací nalezených ve druhé etapě. Vzorky byly odebírány jak na výstupu z úpravny, tak $v$ distribuční síti. $V$ této etapě bylo odebráno 15 vzorků vody z 8 různých lokalit.

\section{Výsledky studie}

Ani $v$ jednom ze vzorků odebraných $v$ první etapě vzorkování nebyla nalezena koncentrace nad MS $(0,5 \mathrm{ng} / \mathrm{l})$ žádné ze sledovaných látek. Ve druhé etapě, kdy byl odběr vzorků upravené pitné vody zaměřen na kritické lokality, kde Ize očekávat nejvyšší koncentrace sledovaných látek, byly jen na čtyřech z 23 sledovaných lokalit všechny nálezy pod MS, v ostatních vzorcích byly nalezeny jedna až tři látky nad MS. Nejvíce záchytů bylo u ibuprofenu (12 v koncentračním rozmezí 0,7 až 20,7 ng/l, s mediánem na úrovni 2,0 ng/l), následováno karbamazepinem (8 záchytů v rozmezí 2,2 až 18,5, $\mathrm{s}$ mediánem na úrovni $5,5 \mathrm{ng} / \mathrm{l}$ ), naproxenem (5 záchytů $v$ rozmezí 0,5 až $3,0 \mathrm{ng} / \mathrm{l}$ ) a diklofenakem ( 2 záchyty na úrovni 0,6 a $3,9 \mathrm{ng} / \mathrm{l}$ ). Ve třetí etapě byly $v$ naprosté většině případů nálezy nižší než ve druhé etapě a u vzorků odebíraných ze sítě byl jen ve 3 vzorcích ze dvou vodovodů zjištěn pozitivní nález - třikrát se jednalo o ibuprofen $(0,5$ $1,2 \mathrm{ng} / \mathrm{l})$, jednou o karbamazepin $(4,0 \mathrm{ng} / \mathrm{l})$. Koncentrace $17 \mathrm{a}$-ethinylestradiolu byly ve všech vzorcích druhé a třetí etapy nižší než MS (2 ng/l).

Nálezy ve vodě odebrané na kohoutku u spotřebitele, které jsou pro hodnocení zdravotního rizika rozhodující, byly vždy nižší nebo dokonce pod mezí stanovitelnosti, i když na výstupu zúpravny vody byla některá léčiva detekována. Jak je to možné? $\checkmark$ některých prípadech dochází v síti k míchání s podzemní vodou, dále se zde asi uplatňuje postupný rozklad léčiv díky jejich oxidaci chlorem (tam, kde je voda dezinfikována) nebo díky jejich biologické degradaci.

\section{Zdravotní riziko}

Z nepř́tomnosti pěti sledovaných látek nebo jejich omezených nálezů nelze ještě činit závěry $v$ tom smyslu, že ve vodě nejsou (nemohou být) žádné stopy (jiných) léčiv. Nicméně vezmeme-li si čtyři z pěti látek jako indikátory, u nichž je vysoká pravděpodobnost jejich záchytu, Ize na základě získaných výsledků usuzovat, že výskyt léčiv $\vee$ pitných vodách $\vee$ ČR je bud' velmi nízký (nedetekovatelný současnými analytickými postupy), nebo velmi málo pravděpodobný. Nicméně u vodovodů, které jako surovou využívají povrchovou vodu odebíranou ze středních nebo dolních toků řek nebo infiltrát ze zdrojů podél těchto částí řek, jsou nálezy některých léčiv nad mez stanovitelnosti reálné. Lze však očekávat nízké koncentrace na úrovni desetin či jednotek ng/l, jen výjimečně hodnoty nad $10 \mathrm{ng} / \mathrm{l}$.

I když u metodik hodnocení rizik ze stopových environmentálních expozic léčiv se dosud vyskytují určité nejistoty, podle dosavadních poznatků nepředstavují tyto hodnoty sledovaných látek pro spotřebitele žádné zdravotní riziko. Ke stejnému závěru dospěla i nedávno vydaná monografie Světové zdravotnické organizace (WHO, 2011). 
Jestliže dosavadní studie nenaznačují, že by s expozicí léčiv z pitné vody, ke které může $v$ některých místech docházet, bylo spojeno nějaké zdravotní riziko, můžeme tuto otázku považovat za hygienicky bezproblémovou? Nemůžeme, protože zde zůstává ještě hledisko psychologické a estetické. Důležitým kritériem pro hodnocení určitých látek nedosahujících zdravotně škodlivých koncentrací je totiž jejich prípadný potenciál vzbuzovat u spotřebitele obavy či odpor. A nemůžeme ani zapomínat na princip předběžné opatrnosti.

Proto je pro vysvětlení tohoto rizika veřejnosti vhodné použít tzv. metodu relativní expozice. Ta je založena na porovnání koncentrace nebo aktivity dané látky (zjištěné pomocí vhodného biotestu) $v$ pitné vodě $s$ koncentrací nebo aktivitou této látky $v$ potravě, popř. S jinou expozicí, kterou veřejnost důvěrně zná a nepokládá ji za rizikovou či důležitou. Považujeme-li např. za minimální léčebnou dávku 1 tabletu (400 mg) ibuprofenu, pak by při námi zjištěném ojedinělém maximu v pitné vodě $(20,7 \mathrm{ng} / \mathrm{I})$ a denní spotřebě 2 I musel člověk pít tuto vodu cca 26 tisíc let (!), aby přijal dávku ibuprofenu odpovídající jedné tabletě, kterou běžně konzumují v ČR statisíce osob. Jako príklad relativní expozice hormonálně aktivním látkám by pak šlo uvést některé studie z USA, protože všechny naše nálezy byly pod mezí stanovitelnosti. Např. Caldwell a kolektiv (2010) porovnávali expozici estrogenům z pitné vody s expozicí estrogenům z běžné stravy (naše strava obsahuje totiž přirozeně určité množství estrogenních látek rostlinného $i$ živočišného původu - např. $v$ mléce). Na základě dat z USA vypočítali podle nejnepř́znivějšího scénáře modelové koncentrace estronu, 17-beta-estradiolu (E2), estriolu a ethinylestradiolu $v$ pitné vodě a pak na základě obvyklé konzumace pitné vody porovnali expoziční dávku těmto látkám z pitné vody s expozicí z potravy (celkové diety u dospělých, resp. 0,42 I mléka denně u dětí). Zjistili, že expozice dětí všem estrogenům (přepočteno na E2 ekvivalent) z pitné vody je při tom nejhorším možném expozičním scénáŕi asi 150 x nižší než expozice z vypitého půl litru mléka, které se dětem doporučuje pravidelně pít. Expozice dospělých estrogenům z pitné vody byla odhadnuta 82 x nižší než expozice estrogenům $z$ běžné stravy.

\section{Komunikace s veřejností přes média}

Protože některé publikované, již zmíněné zprávy o výskytu léčiv $v$ pitné vodě měly spíše poplašný charakter, považovali jsme za vhodné rozšiřit závěry našeho výzkumu mezi širokou veřejnost. Dne 3. 2. 2012 byla rozeslána na 37 e-mailových adres (mezi nimiž byla zastoupena všechna hlavní tištěná i elektronická média, rozhlas i televize) tř́stránková tisková zpráva (Kožíšek \& Jeligová, 2012) s krátkým prưvodním textem. Text zprávy byl podle našeho názoru jednoznačný $s$ jasným vzkazem, že výskyt léčiv $v$ pitné vodě $v$ ČR je ojedinělý jev a nalezené koncentrace jsou natolik nevýznamné, že nepředstavují žádné zdravotní riziko. Pro názornost byl ve zprávě uveden již zmíněný příklad, že i při nalezeném ojedinělém maximu ibuprofenu $(20,7 \mathrm{ng} / \mathrm{l})$ by člověk př̀ denní spotřebě 2 I vody musel pít tuto vodu cca 26 tisíc let, aby príjal dávku ibuprofenu odpovídající jedné tabletě. Název tiskové zprávy byl „První systematické mapování léčiv v pitných vodách v ČR".

Zprávu zpracovala ČTK a ještě téhož dne se objevila na různých internetových zpravodajských serverech (viz tabulka 1) a postupně i dalších médiích (zdravotnické portály, tištěné deníky, rozhlas, pravděpodobně i televize). Celkem jsme zpětně nalezli 19 článků na různých zpravodajských a zdravotnických serverech. Potud bylo vše v pořádku, protože zájem o téma média projevila. Co nás však zarazilo - a zde se zřejmě ukazuje naše nízká vzdělanost $v$ oboru masových médií - byla snaha většiny médií připravit své příspěvky tak, aby se alespoň na první dojem zdálo, že léčiva $v$ pitné vodě představují 
opravdový problém. Ve většině prípadů se naštěstí jednalo pouze o titulek. Perex a text článku obsahovaly většinou jen nepřekroucené informace $z$ tiskové zprávy. Výjimku přestavovaly pouze tn.cz (tzn. televize Nova) a Ahaonline.cz, kde byl značně zavádějící $\mathrm{i}$ text perexu, což však vzhledem k bulvárnímu charakteru obou médií př́liš nepřekvapuje.

Tabulka 1. Nadpisy článků z internetových zpravodajských a na zdraví zaměřených portálů. Pořadí je založeno na subjektivním hodnocení míry senzacechtivosti nadpisu (vzestupně). Odkazy na jednotlivé články jsou dostupné na adrese http://www.szu.cz/centrum-hygieny-zivotniho-prostredi/leciva-media .

\begin{tabular}{|l|l|}
\hline \multicolumn{1}{|c|}{ Zdroj } & \multicolumn{1}{|c|}{ Nadpis } \\
\hline $\begin{array}{l}\text { Florence - časopis moderního } \\
\text { ošetřovatelství }\end{array}$ & První systematické mapování léčiv v pitných vodách v ČR \\
\hline MedNews & SzÚ zjistil ve vodovodní síti stopy léků, zdraví neohrožují \\
\hline ČeskéNoviny.cz & SzÚ zjistil ve vodovodní síti stopy léků, zdraví neohrožují \\
\hline Zpravy.rozhlas.cz & SzÚ zjistil ve vodovodní síti stopy léků. Zdraví neohrožují \\
\hline Česky Metropol & Lidé pijou s vodou z kohoutků i nepatrné množství ibuprofenu \\
\hline Česká televize & V pitné vodě z vodovodu jsou stopy léků, zdraví neohrožují \\
\hline Novinky.cz & $\begin{array}{l}\text { Z vodovodních kohoutků teče i ibuprofen, ale ve zcela } \\
\text { nepatrném množství }\end{array}$ \\
\hline Regiony24.cz & Lidé pijou s vodou z kohoutků i nepatrné množství ibuprofenu \\
\hline Mediafax.cz & Lidé pijou s vodou z kohoutků i nepatrné množství ibuprofenu \\
\hline Lidovky.cz & Pitná voda obsahuje stopy léků, často ibuprofenu \\
\hline iDNES.cz & $\begin{array}{l}\text { Z vodovodu teče i nepatrné množství ibuprofenu, změřil } \\
\text { zdravotní ústav }\end{array}$ \\
\hline Týden.cz & Ve vodě z kohoutku je malé množství ibuprofenu \\
\hline Medicinadnes.cz & V pitné vodě v ČR nalezeny stopy léků \\
\hline Vitalia.cz & Výzkum: ve vodě z kohoutku jsou zbytky léků \\
\hline Eurozprávy.cz & Z kohoutků nám teče „léčivá" voda s ibuprofenem \\
\hline Deník.cz & Fašli léky V PITNÉ vODĚ! \\
\hline Měsíčník zdraví & Z kohoutků teče ibuprofen! \\
\hline Ahaonline.cz & Fe vodě z kohoutku jsou i léky! Nejvíce IBUPROFEN! \\
\hline tn.cz & \\
\hline
\end{tabular}


Proč tedy pocitujeme jisté rozpaky nad způsobem, jakým bylo o výsledcích tohoto výzkumného projektu referováno $v$ masových médiích, když texty byly víceméně $\checkmark$ pořádku a vytváření titulků, které přitáhnou čtenáře, patří k základním pravidlưm práce novináře („titulek je výkladní skřín článku a musí zaujmout na první pohled" (Kasalová \& Závozda, 2012))? Možná náš pocit pramení z toho, že si povrchní čtenář mohl odnést zcela opačnou informaci, než bylo zamýšleno, tj. že voda ve vodovodu je plná léčiv a dalších nebezpečných látek.

K zjištění, zda někteří čtenáři pochopili články opravdu jinak, než byl původní záměr, se $v$ rámci našich možností nabízí pouze nepř́liš reprezentativní metoda, kterou je pročítání diskuzí pod jednotlivými články. Z př́spěvků uvedených $v$ tabulce 1 byly rozsáhlejší diskuze pouze na serverech Novinky.cz a iDNES.cz, ve kterých bylo několik stovek reakcí. Na iDNES.cz jich bylo 451 (poslední z 4. 2. 2012), což je počet, jehož dosahují např. aktuální politická témata. Na serveru Novinky.cz $v$ době, kdy jsme chtěli diskuzi systematicky pročíst, byla již uzavřena a stažena. Pokud si dobře pamatujeme, druhý den po zveřejnění článku zde bylo cca 5 stran diskuze, což odpovídá zhruba 150 příspěvkům. Kromě těch, které se tématu nedotýkají, nebo kterým téma slouží pouze jako zdroj inspirace pro vtipné i rádobyvtipné komentáře (typicky "Až se tohle dozví Heger $s$ Kalouskem, mají důvod k další dani a poplatku... "- uživatel "řezbář" na iDNES), kterých je většina (na iDnes více než $73 \%$ př́spěvků), se zde objevují i negativní reakce, které se dotýkají probíraného tématu. Lze je rozdělit do několika okruhů:

- znechucení nad stavem pitných vod nebo stavem prostředí obecně (nekvalitní potraviny apod.), včetně reakcí zastánců různých konspiračních teorií - na iDnes přibližně $5 \%$ příspěvků,

- kritika financování takového výzkumu, který nic závažného neobjevil, a proto je "o ničem" a tudíž o plýtvání penězi, prípadně, že s dostatečně citlivými př́istroji je možné prokázat cokoli $v$ čemkoli - na iDnes přibližně $4,5 \%$ př́spěvků,

- reakce "environmentálních analfabetư", kteří např. projevovali údiv nad tím, že léčiva v pitných vodách mohou pocházet také z nepoužitých léčiv "spláchlých do záchodu" ("Léčivé látky se do pitných vod dostávají hlavně močí a spláchnutím nepoužitých léčiv do záchodu. - to znamená, že z vodovodu teče splašková voda?" - uživatel „jenik221" na iDNES) - na iDnes přibližně 2,5\% př́íspěvků,

- podezření, že článek je skrytou kampaní výrobců balených vod - na iDnes přibližně $2,5 \%$ přispěvků,

- reakce vlastníků různých typů domácí úpravy vody (tzv. domácích vodních filtrů) a lidí pijících výhradně balené vody - na iDnes přibližně $2,5 \%$,

- reakce vlastníků soukromých studní - na iDnes přibližně $2 \%$ př́spěvků.

Vzhledem $\mathrm{k}$ nesprávnému pochopení a negativním reakcím některých čtenářů (byt́ se jedná alespoň z části o věčné nespokojence nebo osoby, které nemají ponětí např. o hydrologickém cyklu), jsme se samozřejmě zabývali otázkou, zda by nebylo lepší zůstat u obvyklého modelu a informace zveřejnit pouze na webovských stránkách SzÚ, kde by si je zájemci o problematiku mohli sami vyhledat, a případnou větší publicitu nechat na aktivitě novinářù. Čili nesnažit se o aktivní informování veřejnosti a tím se vyhnout riziku dezinterpretace sdělení médii nebo alespoň za ní nenést (díky snaze o medializaci) spoluodpovědnost. Tento přístup by pochopitelně znamenal menší rozšíření informace mezi širokou veřejností. Výhodou by však mohlo být to, že novináři, kteří se rozhodli problematikou zabývat z vlastní iniciativy, o ní budou pravděpodobně informovat 
objektivněji, než ti, kteří dostanou zprávu "naservírovanou" prostřednictvím ČTK. Nabízí se také střední cesta, při níz by informace byla zaslána jen novinářům, u kterých si budeme jisti, že budou snažit o problému referovat objektivně. Ostatně vytvoření dlouhodobých vztahů s redaktory a novináři, založených na důvěře, je jedním z pravidel správné komunikace rizika (Šmerhovský et al., 2005).

K senzacechtivosti některých titulků mohl přispět i fakt, že závěr studie není $z$ hlediska většiny masových médií př́liš zajímavý. Není totiž výrazně negativní (léčiva se ve vodě občas vyskytují, ale nepředstavují riziko) a pro média je atraktivní nebezpečí a nikoliv bezpečí (Šmerhovský et al., 2005). Závěr však není ani výrazně pozitivní (nelze např. tvrdit, že kvalita vody $v$ ČR je nejlepší na světě).

Nebyli jsme také připraveni na to, že nezanedbatelná část čtenářů bude i z nepatrného výskytu léčiv $v$ pitných vodách pobouřena, protože se $z$ jejich pohledu jedná o důkaz souběžného výskytu moči $v$ pitné vodě. Jiné vnímání rizik odbornou a laickou veřejností jsme sice mohli dopředu odhadnout, nicméně informovat o závěrech studie tak, aby u části čtenářů nevznikl nepř́jemný pocit, že $s$ vodou $z$ vodovodu vypijí i malé množství moči, je poměrně obtižné. Lze sice argumentovat, že vzhledem ke koloběhu vody je více než pravděpodobné, že každá molekula vody, kterou pijeme, prošla již předtím opakovaně mnoha organismy, ale ani to určitě nezmění náhled všech čtenářù.

Pokud se $v$ budoucnu objeví téma, které bychom považovali za obdobně zajímavé, zatím jsme nedospěli $k$ jednoznačnému závěru, zda je vhodné $k$ šíření informací opět využít masová média, přestože jsme obecně přesvědčeni, že otevřené a pravdivé informování je základem jakékoli komunikace.

\section{Komunikace výrobce vody s odběratelem (spotřebitelem)}

$\checkmark$ duchu otevřené komunikace jsme formulovali naše doporučení vodárenským společnostem (Kožišek et al., 2011), které v minulých letech ne vždy št́astně na obavy veřejnosti reagovaly, což Ize ilustrovat následujícím př́kladem. Na dotaz novináře, zda se v pitné vodě v krajském městě vyskytují zbytky léků a syntetických hormonů, reagovala mluvčí vodárenské společnosti: "Pitná voda z kohoutku odpovídá všem legislativním normám na pitnou vodu... Zatím jsme rozbory na zbytky léčiv $v$ pitné vodě neprováděli, zejména proto, že jsou velmi drahé a vyhláška je nevyžaduje..." (Anonym, 2011). Z takové odpovědi získává čtenář nutně dojem, že výrobce vody sleduje jen omezený okruh látek daný př́slušnou vyhláškou (která přirozeně obsahuje jen okruh nejčastěji se vyskytujících kontaminant) a o ostatní se nezajímá, a pocit, že o jeho bezpečnost není dostatečně postaráno.

Podle zákona o ochraně veřejného zdraví má spotřebitel (odběratel pitné vody) právo být informován o aktuální kvalitě dodávané vody. I když léčiva nepatří mezi okruh povinně (a ve všech vodovodech) sledovaných látek, zprávami z médií znepokojený spotřebitel se může přirozeně zajímat také o tento okruh látek. Příslušná vyhláška definující kvalitu pitné vody (č. 252/2004 Sb. v platném znění) totiž obsahuje obecný požadavek, že pitná voda nesmí obsahovat mikroorganismy a látky jakéhokoli druhu $\checkmark$ počtu nebo koncentraci, které by mohly ohrozit veřejné zdraví.

Zásada č. 1 by měla pro výrobce vody znít: nestrkat před možnými problémy hlavu do písku a neignorovat obavy spotřebitelů. Výrobci pitné vody musí přijmout skutečnost, že ve vodě se mohou vyskytnout i jiné látky či organismy než ty, které jsou jako minimum definovány pro rutinní kontrolu. Výskyt některých jiných látek může být lokálně dokonce 
mnohem pravděpodobnější než řada rutinně sledovaných ukazatelů. Proto je $v$ zájmu ochrany spotřebitelů potřeba přistupovat $k$ této skutečnosti aktivně a uvažovat, jaká rizika se mohou $v$ mém systému zásobování vyskytnout a zda je mám prostřednictvím současného způsobu monitorování vody a technologických procesů pod kontrolou či nikoliv (Tuhovčák et al., 2010).

Na počátku musí stát základní posouzení, zda je nebezpečí výskytu léčiv pro daný zdroj vody reálné. Zatímco u "pravé" podzemní vody, která není pod vlivem vody povrchové (zatížené odpadními vodami, a to i vyčištěnými), nemůžeme toto riziko považovat za relevantní, odběry povrchové vody na středních a dolních tocích řek považujeme naopak za typickou rizikovou situaci. Mezi tím však může existovat řada přechodů, kde nejsme schopni riziko na základě dostupných dat posoudit. Zde pak není nutno nechat hned stanovit nějaké spektrum léčiv (okamžitě totiž vyvstává otázka - jaké spektrum?), ale Ize nejprve použít jako indikátor např. kofein, který se do vod dostává stejnými cestami jako léčiva, ale vyskytuje se $v$ mnohem vyšších koncentracích, takže jeho záchyt je mnohem pravděpodobnější a analýza nepř́liš složitá. Nebo karbamazepin, který také bývá pro tento účel někdy využíván, protože účinnost jeho odstraňování při čištění odpadních vod i konvenční úpravě pitných vod je velmi nízká.

O závěrech z šetření by pak měl výrobce vody informovat spotřebitele, např. $\mathrm{v}$ časopise pro zákazníky, který většina vodárenských společností vydává, popř. skrze webovské stránky. Pokud by byl výskyt některého $z$ léčiv $v$ distribuované pitné vodě potvrzen, je zároveň nutné interpretovat, jaká je zdravotní relevance takového nálezu. Takovou interpretaci je nutné provést nejlépe ve spolupráci s krajskou hygienickou stanicí nebo jinou odbornou zdravotnickou institucí.

Protože jakékoli legislativní omezení spotřeby léčiv (za účelem zabránění jejich vstupu do vodního koloběhu) je společensky nereálné, může výrobce vody působit na spotřebitele jen cestou osvětových kampaní vůči samotným spotřebitelům, protože oni sami svým, mnohdy nerozumným užíváním všemožných léků a jejich nesprávnou likvidací, stojí na počátku tohoto problému. Takže osvětová kampaň může být namířena na správnou likvidaci nespotřebovaných léčiv (odevzdání do lékárny). Osvěta může být také vedena $v$ obecné rovině vůči všem chemickým látkám a jejich odpovědnému používání např. s poukazem na následky, jaké má jejich výskyt $v$ povrchových vodách pro vodní organismy. Na rozdíl od člověka (při expozici léčiv prostřednictvím pitné vody) je totiž negativní vliv např. hormonálně aktivních látek na ryby i některé jiné vodní organismy prokázán. Neodůvodněné užívání antibiotik vede ke zvyšování rezistence bakterií a $\checkmark$ konečné fázi ohrožuje opět spotřebitele. Nepřímým a dlouhodobým opatřením je jakákoli podpora zdravého životního stylu, která může být později spojena s nižší spotřebou léčiv $\checkmark$ dané populaci. Toto všechno mohou být témata, kterým se Ize v časopise pro zákazníky postupně věnovat.

\section{Anatomie polopravdy}

Vrat́me se ještě jednou $\mathrm{k}$ otázce způsobu, jak média u nás většinou o problematice možného výskytu stop léčiv $v$ pitné vodě referují, resp. $k$ prríčinám tohoto neobjektivního př́stupu. Vidíme za ním tři možné př́činy:

1) Povrchní novinářský př́stup, kdy autor uchopí dílči informaci ze zahraničí, ale nesnaží se zjistit podrobnosti, souvislosti a relevanci pro tuzemské podmínky. 
Snaha o senzaci, kdy se autor záměrně snaží situaci zveličit, aby přitáhl pozornost čtenářù ("Obsah chloru v kohoutkové vodě bereme jako běžnou věc, ale že $v$ ní najdeme i stopy hormonů, je pro mnohé překvapením, avšak odbornými studiemi potvrzeným. Hormony z antikoncepce se do povrchových vod dostávají skrze odpadní vody tekoucí do čističek, kde se dokonce často mění na látky s ještě silnějším účinkem. Odsud putuji do rozvodů pitné vody. Nikdo, ani renomovaní vědci, neumí říct, jaká zdravotní rizika může pití takové vody vyvolat." (Anonym, 2012)).

3) Záměr, kdy ale primárním účelem není zvýšení sledovanosti média, ale určitá reklama, která může ze zkreslení situace profitovat. V úvodu tohoto článku jsme citovali z krátkého sdělení z časopisu Osobní lékař (což byl měsíčník odborně garantovaný Českou lékařskou komorou). Autor sdělení hovoří o nálezech hormonů ve Vltavě pod vyústěním ústřední čistírny odpadních vod v Praze Podbabě, aby vzápětí „přesmyčkou" došel k závěru, že toto je typický nález ve vodovodní vodě velkých měst, včetně Prahy (Anonym, 2002). Byla to jen náhoda, že o několik stránek dále byla celostránková reklama na balenou vodu? Nevíme, ale na jiném př́padě ilustrujeme, že někdy o náhodu určitě nejde.

Koncem léta 2009 vzbudila pozornost občanů i odborníků mediální kampaň „Pije se vám lépe, když víte, co pijete", kterou se Svaz minerálních vod snažil reagovat na klesající spotřebu balených vod a přesvědčit veřejnost, aby pila balené minerální a pramenité vody. Mezi deseti důvody, proč by tak veřejnost měla činit, byl i tento: "Vědecké studie prováděné i $v$ České republice uvádí, že povrchové vody, ze kterých je vyráběna většina vody z kohoutku, mohou obsahovat zbytky hormonů a léčiv..." (Svaz minerálních vod, 2009).

Pomíjíme nyní tvrzení o většině pitných vod vyráběných z povrchových zdrojů (která je většinou více než těsnou - $v$ roce 2009 byl poměr povrchové ku podzemní vodě $51: 49$ $\%$ - nehledě $\mathrm{k}$ již zmíněné skutečnosti, že více než $3 / 4$ surové povrchové vody pochází z chráněných vodárenských nádrží, kde je zatížení odpadními vodami nulové či minimální). Zajímavější je zaměřit se na ony vědecké studie a jejich relevanci pro kvalitu dodávané pitné vody $v$ ČR, protože tvrzení uvedené $v$ kampani mělo ve čtenáři nepochybně vzbudit dojem, že většina pitných vod $v$ ČR může obsahovat zbytky hormonů a léčiv. Podrobnější informace se pak mohl zájemce dozvědět na stránkách Svazu minerálních vod, kde byl uveřejněn čtyřstránkový text doc. Pačese z České geologické služby (Pačes, b.r.). Ten referoval o studii z roku 2000, která sledovala výskyt estrogenů ve Vltavě a jejích prítocích na území Prahy (Morteani et al., 2004 \& 2006). Jen na okraj této studie byly odebrány také tř̌i vzorky pražské pitné vody na výstupu ze všech tř́ tehdy fungujících úpraven $\mathrm{v}$ Podolí, Káraném a na Želivce. Analyzovány byly tyto látky: 17-beta-estradiol, estriol, estron, 17-alfa-ethinylestradiol, mestranol a norethisteron. Zatímco $v$ káranské vodě nebyla detekována žádná látka, $v$ podolské a želivské vodě bylo pět látek nedekovatelných a jedna vždy těsně nad mez stanovitelnosti - $v$ podolské vodě 17 -beta-estradiol $(2,6 \mathrm{ng} / \mathrm{l})$ a $\vee$ želivské vodě 17 -alfa-ethinylestradiol $(2,3 \mathrm{ng} / \mathrm{l})$. Vzorky vody byly analyzovány v Německu (TZW Karlsruhe), mez stanovitelnosti byla $1 \mathrm{ng} / \mathrm{l}$ (Sacher, 2007).

Přestože vzorkování nebylo pro potvrzení nálezu nikdy opakováno a data z podolské vodárny, která není od roku 2002 v provozu, nebyly v době zveřejnění studie již relevantní, je údaj o jednom hraničním nálezu jedné látky (1 nález ze 12 stanovení 6 látek) vydáván za důkaz o výskytu hormonů a zbytků léčiv v pražské pitné vodě (!). Navíc, kdyby se autoři studie nad výší tohoto ojedinělého nálezu 17a-ethinylestradiolu zamysleli, museli by zapochybovat o jeho správnosti - podle některých modelů totiž, nejde-li o bodové znečištění odpadními vodami z výroby této látky (která se $v$ ČR nikde nevyrábí), 
Ize v povrchových a pitných vodách očekávat nejvýše koncentrace do 0,5 ng/l (Hannah et al., 2009).

I když citovaná studie doc. Pačese a kolektivu přináší zajímavé údaje o výskytu sledovaných látek ve VItavě a jejích prítocích, její vypovídací schopnost ve vztahu ke kvalitě pitné vody $v$ Praze je minimální (a mimo Prahu nulová) a nelze ji považovat za žádný vědecký důkaz pro tvrzení o výskytu hormonů v pitných vodách $v$ ČR.

Přesto se Pačesova studie objevila $v$ této souvislosti $v$ médiích již $v$ roce 2007 . Na počátku dubna 2007 pořádala obecně prospěšná společnost Aquasana - Zdravá voda (která sídlí v Karlových Varech a sdružuje hydrogeology zabývající se především přírodními minerálními a léčivými vodami Západních Čech) v Karlových Varech odborný seminář. Těchto úzce specializovaných seminářủ se $v$ předešlých letech zúčastňovala skupina max. 20-25 odborníků. Na seminář v roce 2007 však byli pozváni i zástupci médií a kupodivu se $\checkmark$ hojném počtu dostavili. Hlavním důvodem byly "nové poznatky o výskytu estrogenů v pitných vodách", které zde přednesl doc. Pačes a o kterých v následujících dnech referovala řada médií, včetně televize. Př́íkladem může být zpráva („Pitná voda může škodit zdraví") zpravodajského serveru idnes.cz, ve které autor s odvoláním na odborníky uvádí: „Prưzkum pitné vody v Praze odhalil prítomnost estrogenů, které mohou poškodit zdraví. Jejich působení se projeví až po delši době a $v$ budoucnu mohou predstavovat závažný problém...” (Anonym, 2007). Nebo zpráva z Nedělního Blesku („Miláčku, nepij vodu z kohoutku"), kde autorka píše: „Jak se Nedělnímu Blesku podařilo zjistit z průzkumu Tomáše Pačese z Oddělení geochemie životního prostředí České geologické služby, čistírenské kaly zachytí pouze část estrogenů a malá část opět uniká do vodních toků. 'Otázkou zůstává, zda malé koncentrace těchto látek nemohou projít i úpravnami pro pitné vody, ' píše ve své zprávě Tomáš Pačes. Ten mimo jiné zjistil, že $v$ raadě vodních tokü zásobujících pražskou vodovodní sit' je celková koncentrace estrogenů zvýšená..." (Cejpová, 2007). V obou článcích se také objevuje obdobná rada, jak se tohoto rizika vyvarovat: „... těmito látkami jsou postiženy hlavně povrchové vody. Vody z hlubinných zdrojü jsou v tomto prípadě bezpečné..." (Anonym, 2007), resp. "Jediným způsobem, jak se ženským hormonům s jistotou vyhnout, tak zřejmě züstává pití minerálky..." (Cejpová, 2007).

Souvislost se zde prímo nabízí, zvláště podíváme-li se do dedikace v obou publikacích (Morteani et al., 2004 \& 2006), kdo studii výskytu estrogenů ve Vltavě a jejích prítocích na území Prahy financoval: Karlovarské minerální vody a.s. (!). Není rovněž bez zajímavosti, že mediální kampaň „Pije se vám lépe, když víte, co pijete" byla stažena poté, co Sdružení oboru vodovodů a kanalizací ČR (SOVAK ČR) předložilo Svazu minerálních vod právní memorandum, že kampaní došlo $\mathrm{k}$ porušení několika zákonů a nekalosoutěžnímu jednání, a pohrozilo žalobou. Žádný státní dozorový orgán však v této věci nekonal, přestože se nejen $v$ tomto jednom bodě jednalo o klamavé obchodní praktiky.

\section{Závěr}

$\checkmark$ posledních letech proběhlo či ještě probíhá v zahraničí i u nás několik kampaní na podporu pití vodovodní vody, a to zejména z environmentálních důvodů, protože v porovnání s balenými vodami je tento způsob distribuce pitné vody nejen mnohem levnější, ale především mnohem šetrnější k životnímu prostredí. Základní podmínkou úspěchu podobných kampaní však je, aby lidé měli ve vodovodní vodu důvěru ( $a$ pochopitelně i dobrá kvalita vody jako taková). S tím úzce souvisí i veřejně deklarovaný cíl moderního vodárenství: „Cílem je dobrá nezávadná pitná voda, která se těší důvěře spotřebitelů. Voda, kterou Ize nejen bez obav pít, ale u níž spotřebitel zároveň 
oceňuje její estetickou kvalitu." (IWA, 2004). V rámci udržování či budování důvěry spotřebitelů musí vodárenské společnosti pohližet na kvalitu vody komplexně a ne jen pod úhlem legislativního minima, a činit taková opatření, aby měly výskyt rizikových látek ve vodě, včetně př́padných zbytků léčiv, pod kontrolou; tam, kde je to potřebné, aby možný výskyt těchto látek $v$ upravené vodě minimalizovaly. Systematický př́stup $k$ omezování vstupu těchto látek do vodního koloběhu však musí iniciovat stát, podobně jako je tomu např. v Německu (Kožíšek \& Kožíšková, 2012). Vodárenské společnosti musí zároveň o všem otevřeně a opakovaně informovat své odběratele. Jen tak je možné aspoň částečně čelit cíleným dezinformačním kampaním vedeným proti vodovodní vodě.

Podobně by se měly chovat i orgány hygienické služby jako představitelé státního zdravotního dozoru, které by měly zlepšit své umění komunikace $s$ veřejností. Přes naše výše zmíněné pochybnosti o efektivitě informování veřejnosti skrze média totiž stále předpokládáme, že nezanedbatelná část čtenářu (která má menší chut́ se zapojovat do internetových diskuzí) si sdělení médií vyloží správně, což je patrné i z některých námi zaznamenaných pozitivních príspěvků v diskuzích.

Jednalo se většinou o reakce na nesprávně pochopenou problematiku jinými účastníky diskuze. Jako př́klad můžeme uvést reakci na diskuzní př́spěvek, jehož autor nechápal, proč psát takové články, když nehrozí riziko akutní otravy: "Smysl článku může být taky $v$ tom, aby lidi nevyhazovali léky do záchoda, ale nespotřebované vraceli do lékárny - funguje to $v$ každé lékárně a zdarma" (uživatel "MirekK1" na iDNES). Jako reakce na zveřejněné články o léčivech $v$ pitné vodě se pak $s$ několikadenním zpožděním objevilo prohlášení mluvčího lékárenské komory ke správné likvidaci prošlých léčiv (ČTK, 2012).

A závěrem uvedeme reakci na príspěvek jednoho nespokojence: "Kdybys byl/a co $k$ čemu, tak si nejprve zjistíš, že to vlastně nic neznamená. Je tam tolik léku, jako je šance, že ty získáš nobelovku. nula nula nula nula nic" - anonymní uživatel na Deník.cz. Podobné reakce jsou nadějí, že snaha sdělit široké veřejnosti pozitivní zprávu, že se léčiva $v$ pitné vodě vyskytují v zanedbatelné míře, nebyla úplně marná.

\section{Literatura}

- Anonym, (2002). Hormony jsou i v pitné vodě z vodovodů. Osobní lékař, 2002(2, číslo Speciál, 3),

- Anonym, (2007). Pitná voda může škodit zdraví. iDnes, 19.4.2007, Retrieved from http://zdravi.idnes.cz/pitna-voda-muze-skodit-zdravi-d2yLzdravi.asp?c=A070419 135557 zdravi bad

- Anonym (tau), (2011). Na hormony však vyhláška nepamatuje. Olomoucký deník, 15(15.2.2011),

- Anonym (qr), . Kohoutková voda skrývá „chemická překvapení". Aha!, 7(274), 8.

- Caldwell, D. J., Mastrocco, F., Nowak, E., Johnston, J., Yekel, H., Pfeiffer, D., . . . Anderson, P. D. (2010). An assessment of potential exposure and risk from estrogens in drinking water. Environmental Health Perspectives, 2010(118), 338344.

- Cejpová, H. (2007). Miláčku, nepij vodu z kohoutku. Nedělní Blesk, 15(15. 4. 2007), 20. 
- Čadek, V., \& Kožíšek, F., Pomykačová, I., Jeligová, H., Svobodová, V., (2012). Stopová množství léčiv v pitné vodě v České republice. Vodní hospodárství, 62(1), 6-8.

- Čtk, (2012). Prošlé léky nesplachujte, varuje lékařská komora. Deník.cz, 6. 2. 2012, Retrieved from http://www.denik.cz/z_domova/prosle-leky-nesplachujtevaruje-lekarska-komora.html

- Hannah, R., D'ACO, V. J., Anderson, P. D., Buzby, M. E., Caldwell, D. J., Cunningham, V. L., . . Sumpter, J. P. (2009). Exposure assessment of 17aethinylestradiol in surface waters of the United. States and Europe. Environmental Toxicology and Chemistry, 2009(28), 2725-2732. Retrieved from http://www.scholaruniverse.com/ncbi-linkout?id=19645524 pmid:19645524 http://dx.doi.org/10.1897/08-622.1

- Heberer, T. (2002). Occurrence, fate, and removal of pharmaceutical residues in the aquatic environment: a review of recent research data. Toxicology Letters, 131(1-2), 5-17. Retrieved from http://linkinghub.elsevier.com/retrieve/pii/S0378427402000413 pmid:11988354 http://dx.doi.org/10.1016/S0378-4274(02)00041-3

- IWA (International Water Association - Mezinárodní asociace pro vodu), (2005). The Bonn Charter for Safe Drinking České vydání (Bonnská charta pro bezpečnou pitnou vodu). SOVAK - Časopis oboru vodovodů a kanalizací, 14(7-8), 20-23.

- Kasalová, R., Závozda, J., . Úvod do studia žurnalistiky. . Retrieved from http://issuu.com/centrum medialniho vzdelavani/docs/ vod moa r. kasalov j._z_vozda

- Kozisek, F., Pomykacova, I., Jeligova, H., Cadek, V., \& Svobodova, V. (2013). Survey of human pharmaceuticals in drinking water in the Czech Republic. Journal of Water and Health, 2013(11), 84-97. Retrieved from http://www.nlm.nih.gov/medlineplus/drinkingwater.html pmid:23428552 http://dx.doi.org/10.2166/wh.2013.056

- Kožíšek, F., Čadek, V., Jeligová, H., (2010). Výskyt humánních léčiv v pitných vodách. . SOVAK - Časopis oboru vodovodů a kanalizací, 19(3), 71-75.

- Kožíšek, F., Jeligová, H., Čadek, V., Pomykačová, I., (2011). Problematika výskytu léčiv v pitné vodě z pohledu spotřebitelů a výrobců vody. SOVAK - Časopis oboru vodovodů a kanalizac, 20(12), 412-414.

- Kožišek, F., \& Jeligová, H. (2012). První systematické mapování léčiv v pitných vodách $v$ ČR. Tisková zpráva Státního zdravotního ústavu. . Retrieved from http://www.szu.cz/uploads/documents/chzp/voda/pdf/gacr leciva/Tiskova zprava SZU_leciva_ve_vode.pdf

- Kožíšek, F., \& Kožišková, Y. (2012). Strategie ke snížení průniku zbytků léčiv do surové a pitné vody. SOVAK - Časopis oboru vodovodů a kanalizací, 21(10), 312314.

- Morteani, G., Möller, P., Eichinger, L., Preinfalk, C., \& Paces, T. (2004). Bestimmung von Einzelöstrogenen im Oberflächenwasser des Einzugsgebietes der Stadt Prag (Tschechische Republik. Grundwasser, 9(4), 248-254. Retrieved from 
http://link.springer.com/10.1007/s00767-004-0057-4 http://dx.doi.org/10.1007/s00767-004-0057-4

- Morteani, G., Möller, P., Fuganti, A., \& Paces, T. (2006). Input and fate of anthropogenic estrogens and gadolinium in surface water and sewage plants in the hydrological basin of Prague (Czech Republic).. Environ Geochem Health, 28(3), 257-264. Retrieved from http://toxnet.nlm.nih.gov/cgibin/sis/search/r?dbs+hsdb:@term+@rn+7440-54-2 pmid:16622589 http://dx.doi.org/10.1007/s10653-006-9040-6

- Pačes, T. . Estrogeny - ženské hormony ve vltavské a pitné vodě v Praze. . Retrieved from http://www.pijtezdravouvodu.cz/files/Estrogeny Paces.pdf

- Sacher (Frank), . osobní sdělení 25.4.2007. : TZW: DVGW - Technologiezentrum Wasser, Karlsruhe.

- Pije se vám lépe, když víte, co pijete (desatero, proč pít balenou minerální a pramenitou vodu). Leták otištěný jako celostránková reklama $v$ mnoha denících (např. Metro, 29.9.2009) a dodnes dostupný on-line . : Svaz minerálních vod. Retrieved from http://www.pijtezdravouvodu.cz/files/10_duvodu.jpg

- Šmerhovský, Z., Cikrt, M., Vavřinová, J., Landa, K., (2005). Vybrané kapitoly o komunikaci rizika. Acta hygienica, epidemiologica et microbiologica, 2005(1), Retrieved from http://www.risk-management.cz/clanky/full-2005-01.pdf

- Tuhovčák, L., Ručka, J., Kožíšek, F., Pumann, P., Hlaváč, J., Svoboda, M. a kolektiv, (2010). Analýza rizik veřejných vodovodů. Brno: Akademické nakladatelství CERM.

- Who, (2011). Pharmaceuticals in Drinking-water. WHO/HSE/WSH/11.05. . Ženeva: WHO. Retrieved from http://www.who.int/entity/water_sanitation_health/publications/2011/pharmaceuti cals 20110601.pdf

MUDr. František Kožíšek, CSc.

Státní zdravotní ústav, Oddělení hygieny vody, Šrobárova 48, 10042 Praha 10, email: voda@szu.cz

Univerzita Karlova v Praze, 3. lékařská fakulta, Ústav obecné hygieny, Ruská 87, 10000 Praha 10

Mgr. Petr Pumann

Státní zdravotní ústav, Oddělení hygieny vody, Šrobárova 48, 10042 Praha 10, email: voda@szu.cz 